\title{
DECREASED NK CELL CYTOTOXICITY AND INCREASED T REGULATORY CELLS FACILITATE PROGRESSION OF METASTATIC MURINE MELANOMA
}

Gordana Radosavljevic ${ }^{1}$, Ivan Jovanovic ${ }^{1}$, Katerina Martinova ${ }^{1}$, Danijela Zivic ${ }^{2}$, Nada Pejnovic ${ }^{1}$, Nebojsa Arsenijevic ${ }^{1}$, Miodrag L. Lukic ${ }^{1}$ ${ }^{1}$ Center for Molecular Medicine and Stem Cell Research, Faculty of Medicine, University of Kragujevac, Serbia ${ }^{2}$ Faculty of Medicine, University of Kragujevac, Serbia

\section{SMANJENA CITOTOKSIČNOST NK ĆELIJA I POVEĆANJE REGULATORNIH T LIMFOCITA UBRZAVA METASTAZIRANJE MALIGNOG MELANOMA MIŠA \\ Gordana Radosavljević ${ }^{1}$, Ivan Jovanović ${ }^{1}$, Katerina Martinova ${ }^{1}$, Danijela Živić ${ }^{2}$, Nada Pejnović1, Nebojša Arsenijević1 ${ }^{1}$, Miodrag L. Lukić ${ }^{1}$ ${ }^{1}$ Centar za molekulsku medicinu i istrazivanje maticnih celija, Fakultet medicinskih nauka Univerziteta u Kragujevcu, Kragujevac, Srbija ${ }^{2}$ Fakultet medicinskih nauka Univerziteta u Kragujevcu, Kragujevac, Srbija}

\section{ABSTRACT}

Malignant melanoma is the most aggressive form of skin cancer. Metastatic dissemination in distant organs is one of the hallmarks of melanoma progression. Immunosuppression and tumour escape from immune surveillance are thought to be the major factors responsible for the establishment and progression of melanoma; however, the exact mechanisms leading to decreased anti-tumour immunity are not completely understood. We aimed to analyse the anti-tumour immune response during hematogenous metastasis using a B16-F1 metastatic melanoma model in C57BL/6 mice. At 21 days after tumour cell inoculation, rapid metastatic melanoma growth was observed, reflected through the increased incidence, number and size of metastatic colonies in the lungs (B16-F1). Phenotypic analyses of splenocytes revealed an increased percentage of $C D 3^{+} T$ cells, a markedly reduced percentage of $C D 19^{+} B$ cells and an increased percentage and absolute number of $\mathrm{CD}^{+}{ }^{+} \mathrm{Foxp} 3^{+} T$ regulatory cells. The cytotoxic activities of total splenocytes and isolated NK cells were significantly decreased in tumour-bearing mice. Thus, the metastatic progression of melanoma in this model is associated with diminished NK cytotoxicity, which may be due to an increased expansion of suppressive $C D 4^{+} F_{0 x p} 3^{+} T$ regulatory cells in the spleen.

Keywords: B16-F1, malignant melanoma, metastasis, NK cells, T regulatory cells

\section{SAŽETAK}

Maligni melanom je najagresivnija forma tumora kože. Diseminacija metastatskih ćelija u udaljene organe je glavna karakteristika progresije melanoma. Smatra se da su imunosupresija i izbegavanje imunskog nadzora glavni faktori odgovorni za uspostavljane metastaza, ali precizni mehanizmi odgovorni za oslabljen antitumorski imunski odgovor nisu u potpunosti razjašnjeni. U ovoj studiji, korišćenjem eksperimentalnog modela metastatskog melanoma (B16-F1) u C57BL/6 miševima analizirali smo antitumorski imunski odgovor u toku hematogenih metastatskih procesa. Dvadeset prvog dana nakon ubrizgavanja tumorskih ćelija detektovan je ubrzan rast metastaza malignog melanoma što se ogleda u povećanoj incidenci, broju $i$ veličini metastatskih kolonija u plućima. Fenotipska analiza splenocita ukazuje na povećan procenat $C D 3^{+} T$ limfocita, značajno smanjene $C D 19^{+} B$ limfocita $i$ povećan procenat $i$ apsolutan broj regulatornih $\mathrm{CD}^{+} \mathrm{Foxp}^{+} \mathrm{T}$ limfocita. Citotoksička aktivnost ukupnih splenocita i NK ćelija u slezini je statistički značajno smanjena u miševima kojima su ubrizgane ćelije malignog melanoma. Dobijeni rezultati u ovom eksperimentalnom modelu ukazuju da metastatskoj progresiji melanoma značajno doprinosi smanjena ubilačka sposobnost NK ćelija koja je najverovatnije posledica zabeležene ekspanzije imunosupresivnih regulatornih $C D 4^{+}$Foxp $^{+}{ }^{+}$T limfocita u slezini.

Ključne reči: $B 16-F 1$, maligni melanom, metastaze, NK ćelije, regulatorni $T$ limfociti
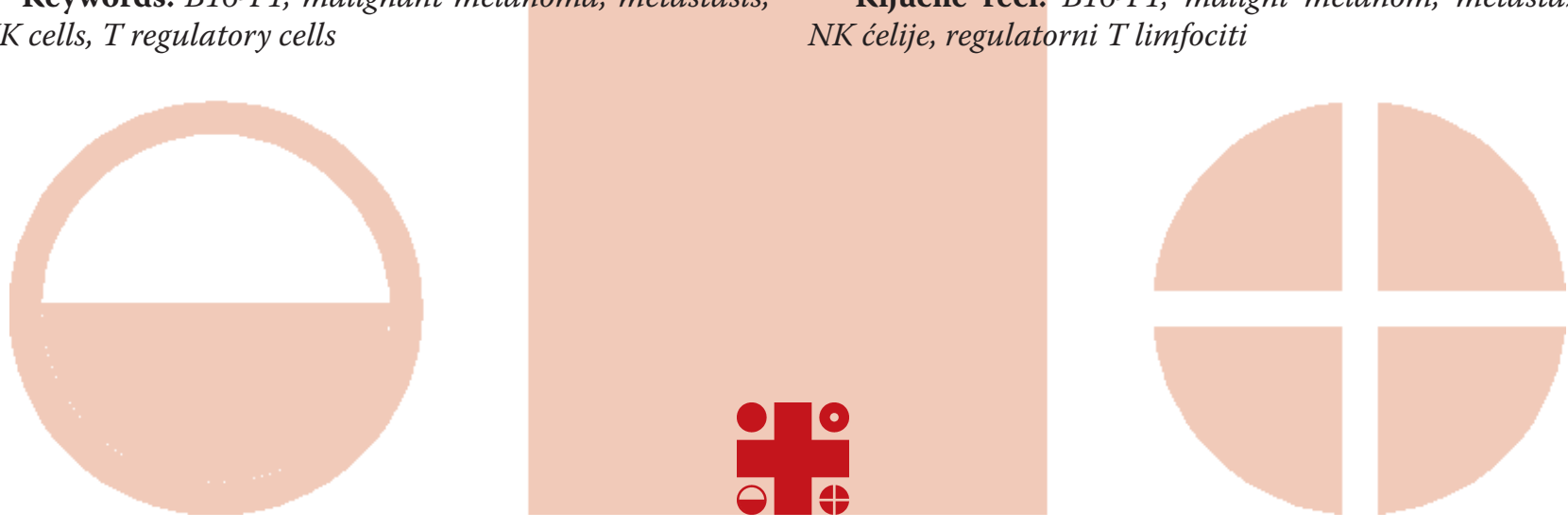

UDK: 616-006.81-033.2 / Ser J Exp Clin Res 2012; 13 (3): 85-92 DOI: 10.5937/SJECR13-1726 


\section{INTRODUCTION}

Malignant melanoma is the most aggressive form of skin cancer. This disease arises from the malignant transformation of melanocytes, a complex process that involves the activation of multiple oncogenes and the inactivation of tumour suppressor genes $(1,2)$. Metastatic tumour cells are characterised by their motility, ability to invade the surrounding tissues and enter the bloodstream, ability to survive the transit through the body and their ability to colonise distant organs (3). The invasion of malignant melanocytes, with subsequent metastatic dissemination and tumour growth in distant organs or tissues, is the hallmark of melanoma progression (4).

The metastatic spread of tumour cells involves interactions between tumour and immune cells (5), during which immune cells could either eliminate tumour cells and attenuate the metastasis or facilitate the metastatic dissemination (6). The role of anti-tumour immunity in metastatic melanoma growth is not completely understood. $\mathrm{CD} 8^{+} \mathrm{T}$ cell-mediated cellular immunity against melanoma-associated antigens has been shown to play an important role in the anti-tumour immune response in experimental melanoma models (7). However, in patients with melanoma, these melanoma-specific $\mathrm{CD} 8^{+} \mathrm{T}$ cells are not efficient in controlling tumour progression. Thus, it appears that the role of $\mathrm{CD} 8^{+}$cytotoxic $\mathrm{T}$ cells is variable and could be related to the immunosuppressed state associated with advanced tumours $(8,9)$.

The immunosuppressive tumour microenvironment may be a major obstacle for the development of effective tumour-specific immune responses. Recent studies of malignant melanoma have demonstrated that the number of regulatory $\mathrm{CD} 4^{+} \mathrm{CD} 25^{+} \mathrm{Foxp} 3^{+} \mathrm{T}$ cells in the peripheral blood and within tumours is elevated, suggesting that these cells play a role in the induction of antigen-specific, local immune tolerance at tumour sites $(10,11)$.

Natural killer (NK) cells, a key component of the innate immunity pathway, are cytolytic cells that recognise and kill malignant cells without prior sensitisation $(12,13)$. NK cells are able to eliminate malignant cells from the circulation and thus serve as the earliest effectors against the dissemination of hematogenous metastasis [reviewed in (13)]. Natural Killer Group 2 Member D (NKG2D) is a powerful activating NK cell receptor that recognises various ligands on malignant transformed cells, such as MICA/B in humans and H60 and RAE-1 in mice (14). Natural regulatory T cells were shown to directly inhibit NKG2D-mediated NK cell cytotoxicity and suppress NK cell-mediated tumour rejection (15).

$B$ cells are the effector cells of humoral immunity, and their role in antitumour immunity is not yet clear. Some studies suggest that these cells play a dual role in tumour-specific cellular immunity. For example, B cells can positively regulate cellular immune responses by serving as antigen-presenting cells and/or by providing costimulatory signals that can induce tumour-specific cytotoxic $\mathrm{T}$ cell activation (16-18). On the other hand, regulatory B cells (B10 cells) can negatively regulate inflammation and immune responses through the production of IL-10 (19-21). It has also been reported that
B cells enhance premalignancy by potentiating chronic inflammation $(22,23)$. The antibodies produced by activated B cells home to premalignant lesions and modulate chronic inflammation by cross-linking the FcR on resident leukocytes. This activity results in rapid degranulation and the release of proinflammatory mediators that further enhance the cascade of activation and recruitment of innate immune cells (23).

In the present study, we aimed to analyse anti-tumour innate and adaptive immune responses during hematogenous metastasis using the B16-F1 metastatic melanoma model in C57BL/6 mice.

\section{MATERIALS AND METHODS}

\section{Mice}

Eight to ten-week-old female and male C57BL/6 mice (purchased from the Military Medical Academy, Belgrade, Serbia) were used as model hosts for experimental metastatic melanoma. Mice were housed under standard laboratory conditions. The experiments were approved by the Ethics board of the University of Kragujevac Faculty of Medicine.

\section{Murine melanoma cell line B16-F1}

The murine skin melanoma cell line B16-F1, which is syngeneic to the C57BL/6 background, was purchased from the American Type Culture Collection (CRL-6323; ATCC, USA). The cells were routinely cultured as previously described $(24,25)$.

\section{Estimation of in vivo metastasis in B16-F1 mouse melanoma model}

For inoculation, B16-F1 melanoma cells were harvested at $~ 90 \%$ confluency using $0.25 \%$ trypsin and $0.02 \%$ EDTA in phosphate buffered saline (PBS; PAA Laboratories GmbH). Cells were washed once in complete medium and twice in DMEM before inoculation. The viability of tumour cells was determined using the trypan blue assay, and only cell suspensions with $\geq 95 \%$ viable cells were used.

An experimental metastasis assay was performed by the intravenous injection of $5 \times 10^{4} \mathrm{~B} 16-\mathrm{F} 1$ cells, in a volume 0.2 $\mathrm{ml}$, into the lateral tail vein of syngeneic $\mathrm{C} 57 \mathrm{BL} / 6$ mice, as described previously (26). The mice were sacrificed on day 21 following melanoma cell injection, and lung, liver and brain tissues were removed for histological examination (24).

\section{Splenic cell preparation}

At 12 days after tumour cell injection, mice were sacrificed, and single-cell suspensions from spleens were obtained by mechanical dispersion through a cell strainer (BD Pharmingen, USA) in complete growth medium. Pellets were resuspended in red blood cell lysis solution, washed three times and resuspended in complete growth medium.

\section{Phenotyping of splenocytes}

The following anti-mouse mAbs were used: CD3, CD4, CD8, CD3e, CD19, F4/80 and NK1.1 (BD Pharmingen/ 
eBioscience, USA). Appropriate isotype control antibodies were used to assess the level of specific labelling. Dead cells were excluded by gating out propidium iodide-positive cells. For intracellular Foxp3 staining, cells were fixed and permeabilised with permeabilisation buffer (BD Pharmingen, USA). Permeabilised cells were stained with antimouse Foxp3 mAbs (BD Pharmingen). Stained cells were analysed using a FACSAria Flow cytometer (BD, USA). The gate used for FACS analysis was the mononuclear cell region in the FSC/SSC plot. The data were analysed using CELLQUEST software (BD, USA).

\section{Adherent cell separation}

Single-cell suspensions of the spleens were incubated for $2 \mathrm{~h}$ in complete media on plastic Petri dishes that had previously been covered with FBS. The non-adherent cells were removed by vigorously washing with DMEM, and the adherent cells were collected by gentle scraping with rubber policemen.

\section{NK cell and $C D 8^{+}$T cell separation}

NK cells were isolated from splenocyte suspensions by magnetic cell sorting. Single-cell suspensions of splenocytes were labelled using microbeads conjugated to monoclonal anti-mouse CD49b (DX5) antibodies (Miltenyi Biotec, USA) and positively selected as previously described (24). CD8 ${ }^{+} \mathrm{T}$ cells were negatively selected from single-cell suspensions of splenocytes using a Dynal mouse T cell negative isolation kit (Invitrogen) as previously described (27).

\section{Cytotoxicity assay}

The cytotoxic activities of splenocytes, adherent cells, $\mathrm{CD}^{+} \mathrm{T}$ cells and NK cells were measured using a 4-h MTT (3-(4,5-dimethylthiazol-2-yl)-2,5-diphenyltetrazolium bromide) assay. Isolated splenocytes, adherent cells, CD8 ${ }^{+} \mathrm{T}$ cells and NK cells were used as effector cells (E), and B16F1 melanoma cells were used as target cells (T). MTT cytotoxicity assays were performed as previously described (28).
The percentage of cytotoxicy was calculated as: cytotoxicy $(\%)=[1-($ experimental group $(\mathrm{OD}) /$ control group $(\mathrm{OD}))] \times$ 100 . The data were expressed as the mean \pm SD of triplicate wells. Cytotoxic capacity was also presented in lytic units, LU20/10 ${ }^{7}$ cells, which were calculated from the means of triplicates percentages of killing obtained at four different $\mathrm{T}$ : $\mathrm{E}$ ratios. The estimated numbers represent the mean values.

\section{Statistical analysis}

The data were analysed using SPSS version 13. Statistical significance was evaluated using the Student's t-test. The normal data distribution was evaluated by the Kolmogorov-Smirnov test. The results were considered significantly different when $\mathrm{p}<0.05$.

\section{RESULTS}

\section{The detection of metastatic melanoma growth in the lung}

Metastatic melanoma was established in syngeneic C57BL/6 mice by the intravenous injection of $5 \times 10^{4} \mathrm{~B} 16-\mathrm{F} 1$ cells into the lateral tail vein. On day 21 following tumour cell injection, all mice were sacrificed, and the lungs, liver and brain were investigated for the presence of metastatic colonies. Metastatic colonies were evident in the lung tissue; eleven out of twelve mice (92\%) developed numerous lung metastases, as shown in Figure 1A. Metastatic colonies were not observed in other parenchymal organs at this timepoint (data not shown).

The injection of B16-F1 malignant melanocytes causes an increase in the percentage of $\mathrm{CDB}^{+}$cells and a decrease of the percentage of $C D 19^{+} \mathrm{B}$ cells in the spleen

The proportions of splenocyte cell populations may be altered in a tumour-bearing host (29). Therefore, we characterised and quantified the immune cells in the spleen 12 days after melanoma cell injection in comparison with splenocytes from healthy mice.
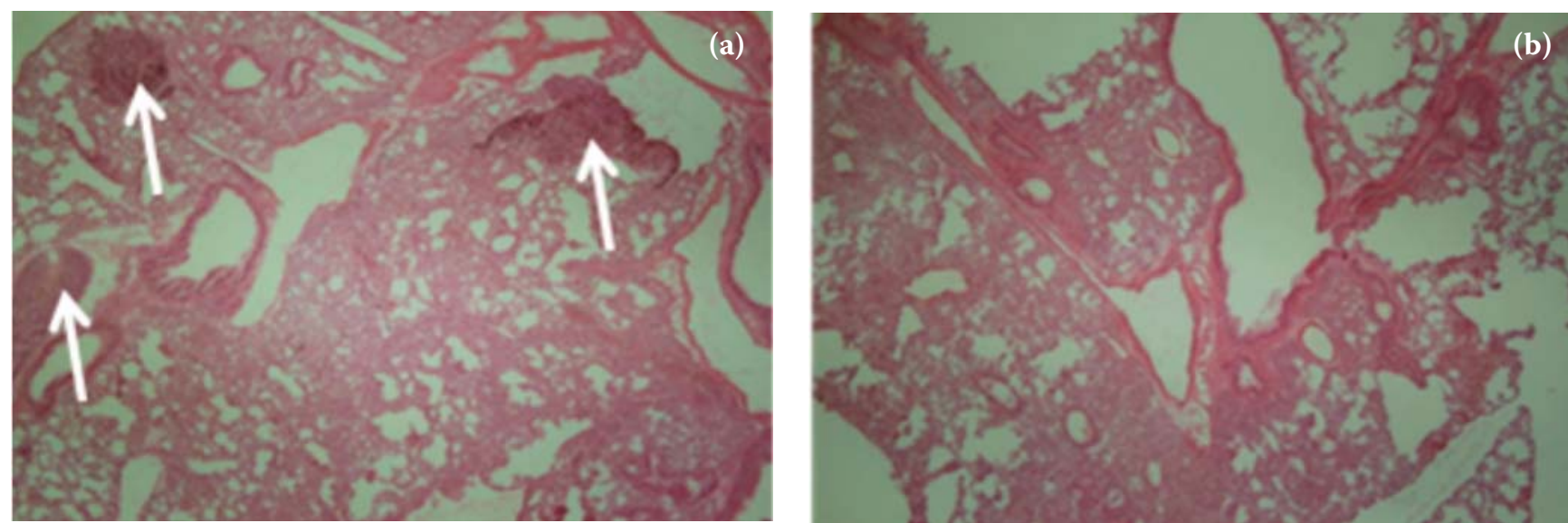

Figure 1. Metastatic melanoma growth in the lungs of C57BL/6 mice, 21 days after inoculation with B16-F1 cells

Fresh frozen lung tissues were stained with hematoxylin and eosin (H\&E) and examined by light microscope for the number and size of metastatic colonies. H\&E-stained sections $(4 \mathrm{~mm})$ from at least three different levels were analysed. A. Histological section across the lung of a mouse bearing B16-F1 melanoma cells (original magnification $10 \times$ ) showing metastatic colonies (arrows). B. Histology of a lung section from a mouse without lung metastasis. 
(a)
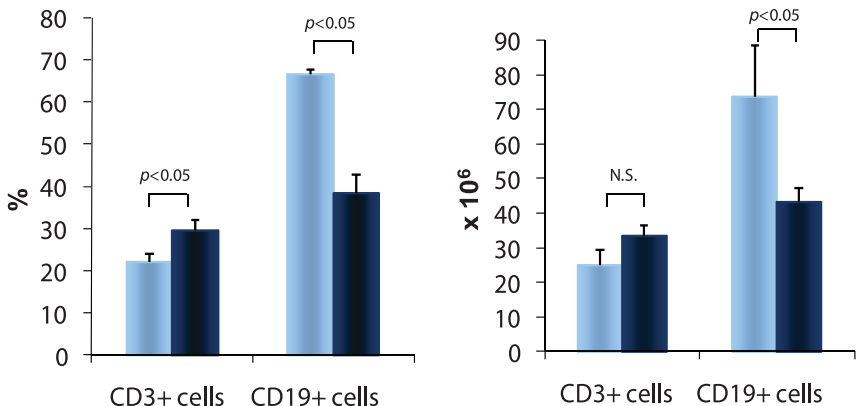

(b)

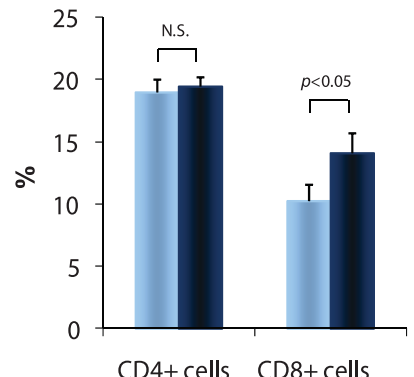

(c)
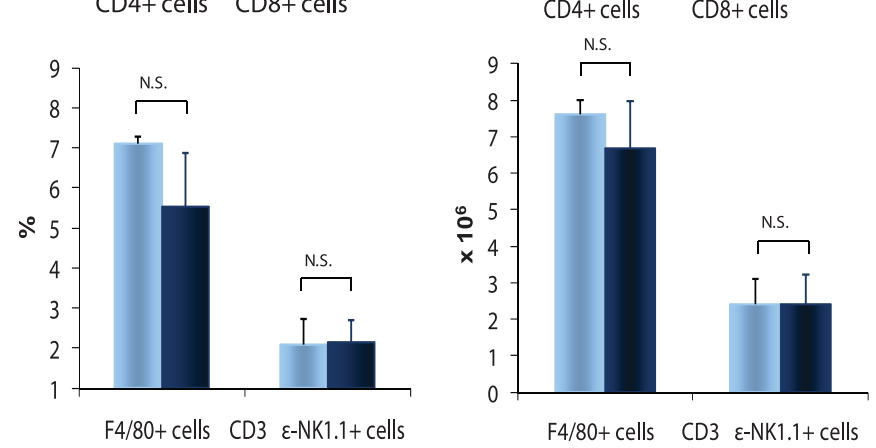

Figure 2. Flow cytometric analysis of splenocytes from naive and melanoma-injected $\mathrm{C} 57 \mathrm{BL} / 6$ mice

A. and B. Injection of B16-F1 malignant melanocytes causes a statistically significant increase in the percentage of $\mathrm{CD}^{+} \mathrm{T}$ cells $(\mathrm{p}<0.05 ; \mathrm{M} \pm$ SD: $21.92 \pm$ 1.05 vs. $29.59 \pm 1.17$, left panel), which is most likely due to the increase in the percentage of $\mathrm{CD} 8^{+}$cells $(p<0.05$; $10.23 \pm 0.81$ vs. $14.04 \pm 0.92$, left panel). The percentage of $\mathrm{CD} 19^{+} \mathrm{B}$ cells was drastically reduced $(\mathrm{p}<0.05 ; 66.70 \pm 0.46$ vs. $38.33 \pm 2.19$, left panel). There was no significant increase in the absolute number of $\mathrm{CD}^{+} \mathrm{T}$ cells (N.S; $25.02 \pm 4.15$ vs. $33.37 \pm 3.14$, right panel) or CD8 ${ }^{+}$cells (N.S; $11.47 \pm 1.64$ vs. $15.69 \pm 1.32$, right panel), while the absolute number of $\mathrm{CD} 19^{+} \mathrm{B}$ cells was decreased after tumour cell inoculation ( $\mathrm{p}<0.05 ; 73.52 \pm 15.00$ vs. $43.07 \pm 4.32$, right panel). In addition, there was no significant increase in the percentage (N.S; $18.96 \pm 1.03$ vs. $19.46 \pm 0.75$, left panel) or absolute number of CD $4^{+}$cells (N.S; $21.01 \pm 2.09$ vs. $22.01 \pm 2.31$, right panel). C. There was no significant change in the percentage (N.S; $1.68 \pm 0.33$ vs. $2.08 \pm 0.33$, left panel) or absolute number of CD3e $\mathrm{NK} 1.1^{+}$cells in the spleen (N.S; $1.63 \pm 0.22$ vs. $2.41 \pm 0.35$, right panel) at 12 days after tumour inoculation. Similarly, there was no significant change in the percentage (N.S; $7.11 \pm 0.09$ vs. $5.54 \pm 1.67$, left panel) or absolute number of $\mathrm{F} 4 / 80^{+}$cells in the spleen (N.S; $7.63 \pm 0.38$ vs. $6.68 \pm 1.30$, right panel) after tumour cell inoculation. The data are presented as the mean \pm SD of at least four mice per group. Statistical significance was tested by the Student's t-test. N.S. (not statistically significant).

The total number of mononuclear cells in the spleen was not significantly affected after the injection of B16-F1 malignant melanocytes (data not shown). As shown in the left panel of Figure 2A, there was a statistically significant increase in the percentage of $C D 3^{+} \mathrm{T}$ cells $(\mathrm{p}<0.05)$ due to the increase in the percentage of $\mathrm{CD}^{+}$cells $(\mathrm{p}<0.05$; Figure $2 \mathrm{~B}$, left panel). Furthermore, the percentage of $\mathrm{CD} 19^{+} \mathrm{B}$ cells was drastically reduced $(\mathrm{p}<0.05$; Figure $2 \mathrm{~A}$, left panel). The absolute number of subsets (Figure 2, right panels) correlates with these findings, while the absolute number of $\mathrm{CD} 19^{+} \mathrm{B}$ cells was again significantly reduced $(\mathrm{p}<0.05$; Figure $2 \mathrm{~A}$, right panel). There were no significant changes in the percentages or absolute number of $\mathrm{CD} 44^{+}$cells, NK (CD3 $\varepsilon$ NK1.1 $1^{+}$cells, or macrophages $\left(\mathrm{F} 4 / 80^{+}\right)$in the spleen on day 12 after tumour inoculation (Figure 2B and 2C, left panel).

The number of $\mathrm{CD} 4^{+} \mathrm{Foxp} 3^{+} \mathrm{T}$ regulatory cells in the spleen is elevated after melanoma cell inoculation

We next investigated whether the number of regulatory $\mathrm{CD}^{+}{ }^{+} \mathrm{Foxp}^{3^{+}} \mathrm{T}$ cells in the spleen is altered after melanoma cell inoculation. Flow cytometric analysis showed that the injection of melanoma cells resulted in a significant increase in the percentage and absolute number of CD4 ${ }^{+} \mathrm{Foxp}^{+} \mathrm{T}$ cells $(\mathrm{p}<0.05$, Figure 3). It appears that regulatory $\mathrm{T}$ cells may facilitate tumour metastasis by promoting an immunosuppressive environment.

\section{A diminished NK cell-mediated anti-melanoma re- sponse in the spleen}

We examined in vitro cytotoxic activity of splenocytes against tumour cells at the target-effector (T:E) ratios of 1:100, 1:50, 1:20 and 1:10. These cells were isolated before and on days 12 after i.v. injections of B16-F1 melanoma cells and were tested for cytotoxic activity against the melanoma cells using MTT assay. As shown in Figure 4A and 4B, cytotoxicity of total splenic cells was diminished after tumour cell injection.

To identify the type of effector cells that is responsible for the diminished cytotoxic capacity of splenocytes, we isolated adherent cells, CD8 ${ }^{+} \mathrm{T}$ cells and $\mathrm{CD} 49 \mathrm{~b}^{+} \mathrm{NK}$ cells and tested their anti-tumour cytotoxicity. We did not find any differences in the cytotoxicity of adherent cells between naive and melanoma-bearing mice (Figure $4 \mathrm{C}$ and $4 \mathrm{~F}$ ). We next tested the cytotoxic activity of $\mathrm{CD} 8^{+} \mathrm{T}$ cells against tumour cells. As shown in Figure 4D and $4 \mathrm{~F}$, significant tumour-specific $\mathrm{CD} 8^{+} \mathrm{T}$ cell-mediated cytotoxicity was observed in control mice $(p<0.05)$. Remarkably, we found that the cytotoxic activity of NK cells in the spleen was diminished after tumour cell injection (Figure 4E and 4F). The obtained results indicate that impaired NK cell cytotoxicity may be associated with diminished anti-melanoma immune response during hematogenous metastasis. 


\section{DISCUSSION}

In the present study, we observed rapid metastatic melanoma dissemination in the lung tissue (B16-F1), reflected through the increased incidence, number and size of metastatic colonies. Our data show that hematogenous metastasis is accompanied by an increase in the percentage of $\mathrm{CD}^{+} \mathrm{T}$ cells, which is most likely due to an increased percentage of $\mathrm{CD} 8^{+}$cells and a drastically reduced percentage of $\mathrm{CD} 19^{+} \mathrm{B}$ cells in the spleen. In our tumour model, diminished cytotoxicity of total splenic cells and NK cells is associated with an increase in the percentage and absolute number of $\mathrm{CD}^{+}{ }^{+} \mathrm{Foxp}^{+} \mathrm{T}$ regulatory cells. These results suggest that the spread of metastatic melanoma was mainly associated with decreased NK cell cytotoxicity, with a possible role for the suppressive activity of an increased proportion of Treg cells.

The B16 cell line is derived from a spontaneous tumour isolated from a C57BL/6 mouse. It is a highly aggressive tumour, and more importantly, it is similar to human melanoma in its propensity for metastasis and low MHC expression (30). In the current study, on day 21 following i.v. injection of B16-F1 (murine melanoma variant cell line), we demonstrated rapid metastatic melanoma growth in the lung tissue, reflected through an increased incidence, number and size of metastatic colonies. Eleven out of twelve C57BL/6 mice (92\%) developed numerous lung metastases (Figure 1A).
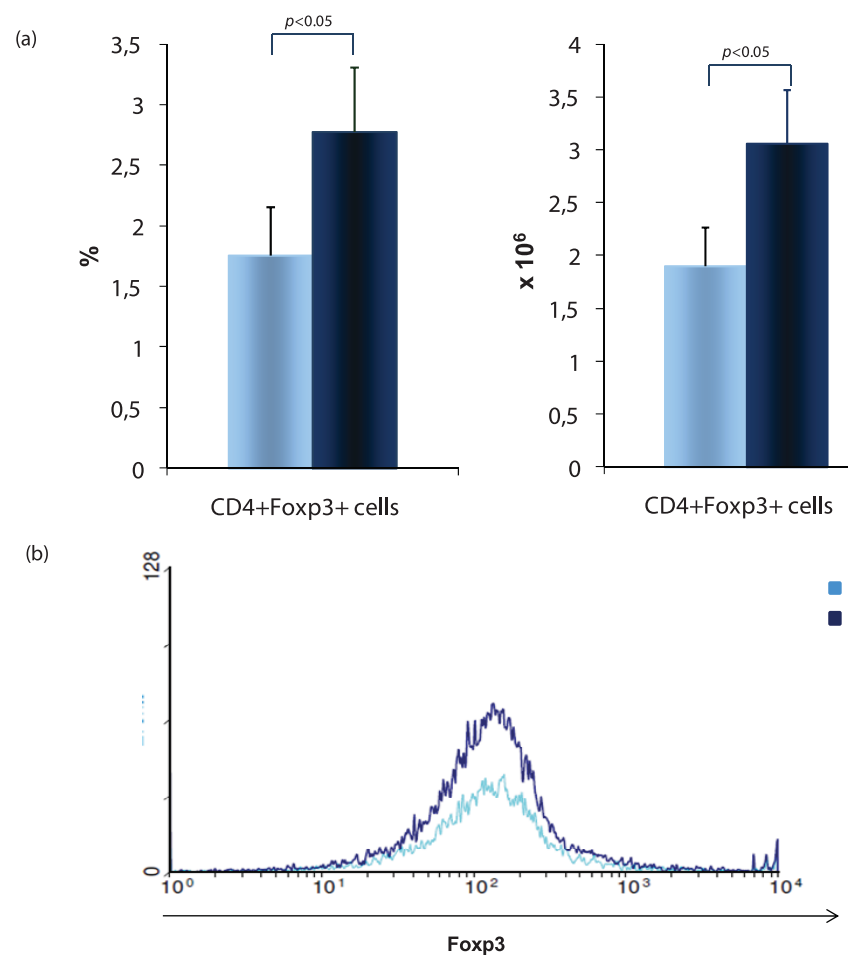

The spleen, a secondary lymphoid organ, may be involved in the anti-tumour immune response, and a relationship between splenectomy and lung metastasis has been reported $(31,32)$. We noticed that at 12 days after inoculation, the percentage and absolute number of $\mathrm{CD}^{+} \mathrm{T}$ cells were significantly increased in the spleen. This change is most likely due to the increased frequency of $\mathrm{CD}^{+}$cells, as the frequency and number of $\mathrm{CD} 4^{+}$cells was not altered. Interestingly, we noticed a marked reduction in the percentage and number of $\mathrm{CD} 19^{+} \mathrm{B}$ cells in the spleens of tumour-injected mice (Figure 2A), which could be required for optimal cellular immune responses against B16 tumours in vivo (33). DiLillo et al (33) reported that $B$ cell depletion reduces the generation of effector/memory and cytokine-secreting $\mathrm{CD} 4^{+}$and $\mathrm{CD} 8^{+} \mathrm{T}$ cells as well as the activation and proliferation of tumour-specific $\mathrm{CD}^{+} \mathrm{T}$ cells. These data suggest that impaired $\mathrm{T}$ cell activation and effector-memory cell generation in the absence of $\mathrm{B}$ cells is likely to promote tumour growth and metastasis. It has also been reported that the number of NK cells and B cells in the bone marrow and spleen of tumour-bearing mice are reduced. This correlates with a decrease in the number of common lymphoid progenitors, suggesting that the tumour growth can lead to reduced lymphopoiesis (29). However, in our tumour model, we found a reduced number of B cells and an increased number of $\mathrm{T}$ cells, and we did not find any differences in the number NK cells or macrophages before and after injection of melanoma cells (Figure 2C).

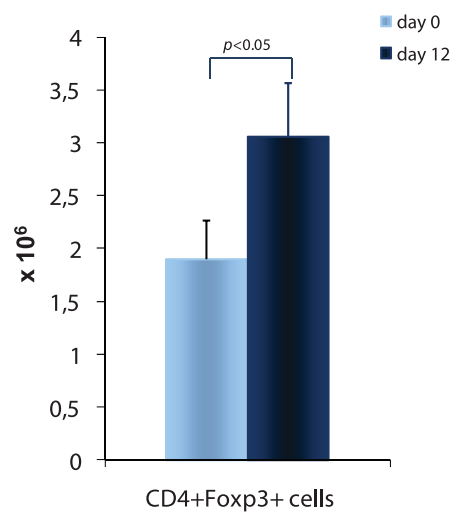

day 0

- day 12

Figure 3. The injection of B16-F1 malignant melanocytes causes an increase in the percentage and number of $\mathrm{CD}^{+}{ }^{+}$Foxp $3^{+} \mathrm{T}$ cells in the spleen of $\mathrm{C} 57 \mathrm{BL} / 6$ mice

A. Melanoma cell-inoculated mice have a higher percentage ( $\mathrm{p}<0.05 ; 1.75 \pm 0.4$ vs. $2.77 \pm 0.54$, left panel) and absolute number of $C D 4{ }^{+}$Foxp $3^{+} \mathrm{T}$ regulatory cells than do naive mice ( $\mathrm{p}<0.05 ; 1.9 \pm 0.36 \mathrm{vs}$. $3.06 \pm 0.5$, right panel). B. A diagram illustrating the percentage of regulatory $\mathrm{CD} 4{ }^{+} \mathrm{Foxp} 3^{+} \mathrm{T}$ cells on the 0th (light blue) and 12th day after i.v. injection of B16-F1 cells (dark blue). The data are presented as the mean \pm SD of at least four mice per group. Statistical significance was tested by the Student's t-test. 
(a)

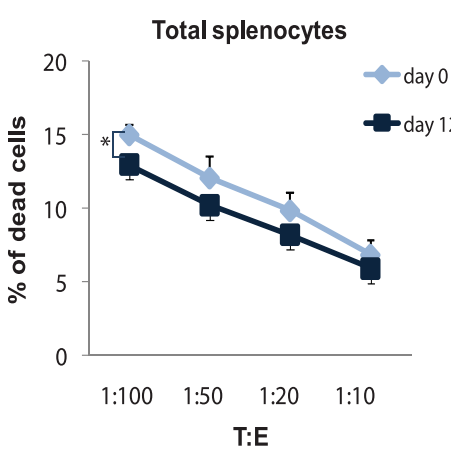

(c)

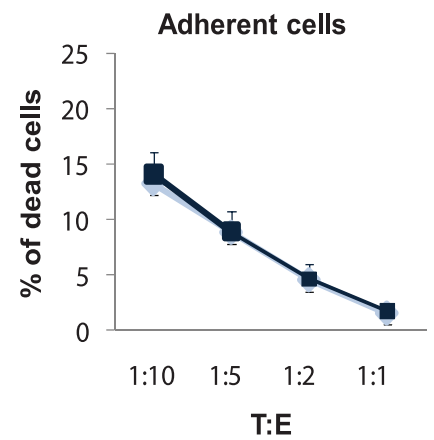

(e)

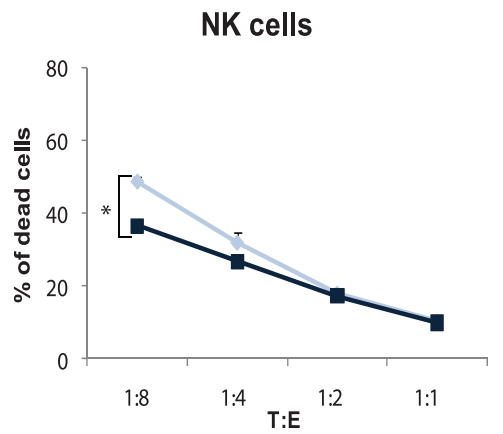

(b)

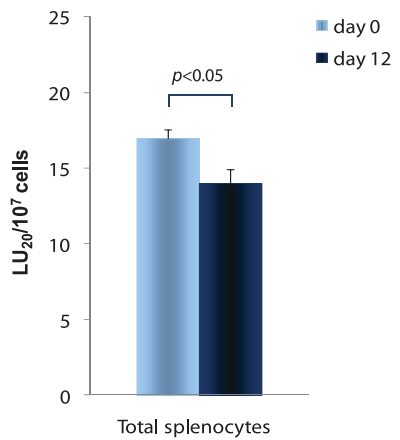

(d)

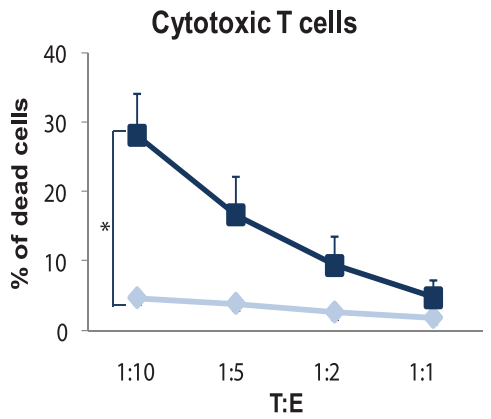

Figure 4. The cytotoxic activity of total splenocytes and different effector cells in the spleen.

The cytotoxic activity of effector cell populations was tested in a 4-h MTT assay against B16-F1 cell targets, at four different T:E ratios, on day 12. A. and B. The cytotoxicity of total splenic cells were diminished in melanoma cell-injected mice compared to naive mice. $\mathrm{C}$. and $\mathrm{F}$. There was no difference in the cytotoxicity of splenic adherent cells in naive and melanoma cell-inoculated mice. D and F. There was a significant increase in $\mathrm{CD}^{+}{ }^{+} \mathrm{T}$ cell-mediated cytotoxicity in the spleens of tumour cell-inoculated mice compared with naive mice. E. and F. The cytotoxic activity of NK cells in the spleen was diminished in melanoma cell-inoculated mice. The data are presented as the mean percentages of specific cytotoxicity and LU20/10 7 cells, which was calculated from the mean percentages of killing in four different $\mathrm{T}: \mathrm{E}$ ratios and the percentages of effector cells found in the spleen. The data are presented as the mean \pm SD from at least four mice per group. Statistical significance was tested by the Student's t-test. N.S. (not statistically significant).

It has been suggested that the interactions between malignant cells and immune cells in the tumour microenvironment create an immunosuppressive network that protects the tumour from immune attack, permitting tumour progression (34-37). Recent studies suggest that $\mathrm{T}$ regulatory (Treg) cells are important cellular components of an immunosuppressive network that stimulates tumour growth and metastasis (38). We showed that the injection of melanoma cells resulted in a significant increase in the percentage and

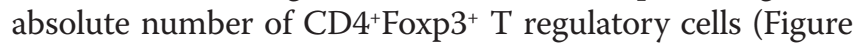
3). It appears that Tregs may facilitate tumour metastasis by promoting the formation of the immunosuppressive environment. The depletion of Treg cells was shown to facilitate tumour rejection in animal studies, implying that these cells suppress immune response against tumour cells $(39,40)$.

Next, we also noticed that the cytotoxic activity of total splenic cells was diminished by day 12 after melanoma cell injection (Figure 4A and 4B). To define the effector cells responsible for the diminished cytotoxic capacity of splenocytes, we isolated adherent cells, CD8 ${ }^{+} \mathrm{T}$ cells and NK cells and tested their cytotoxicity against tumour cells. We did not find any difference in the cytotoxicity of adherent cells of na- ive and melanoma cell-inoculated mice (Figure 4C and 4F), but $\mathrm{CD}^{+} \mathrm{T}$ cells from tumour-inoculated mice were more cytotoxic than those from naive mice (Figure 4D and 4F). Tumour immunity depends on factors other than T-cells, and numerous studies in hematopoietic and solid tumours have revealed that NK cell activation and cytotoxicity are related to patient outcome (41-43). Remarkably, we found that the cytotoxicity of NK cells in the spleen was diminished after melanoma injection (Figure 4E and 4F). Our results indicate that impaired NK cell cytotoxicity may be associated with diminished anti-tumour immune response during hematogenous metastasis. The diminished cytotoxicity of total splenic cells and NK cells may be due to an increase in the frequency and absolute number of splenic $\mathrm{CD} 4{ }^{+}{ }^{+}$oxp $3^{+} \mathrm{T}$ regulatory cells. An inverse correlation between NK cell activity and Treg cell expansion is also found in cancer patients (44). There is evidence that Treg cells might hamper NK cell activation [reviewed in ref (45)]. For example, the suppressive effect of Tregs on the cytotoxicity of NK cells is in large part a result of the down-regulation of NKG2D mediated by TGF- $ß$ (44), and Tregs seem to rather selectively inhibit NKG2D-mediated NK cell cytotoxicity $(15,44)$. 
Taken together, our results suggest that melanoma suppress innate anti-tumour immunity and facilitate metastasis, in part due to the increased expansion of $\mathrm{CD}^{+}{ }^{+}$Foxp $3^{+} \mathrm{T}$ regulatory cells in the spleen.

\section{Acknowledgments and Funding:}

We thank Milan Milojevic for excellent technical assistance. This work was funded by grants from the Ministry of Education and Science of Serbia (Grants OP 175071 and OP 175069) and by the Faculty of Medicine of the University of Kragujevac, Serbia (Grant JP 01/10).

\section{REFERENCES:}

1. DeVita VT Jr, Lawrence TS. and Rosenberg SA. DeVita, Hellman, and Rosenberg's Cancer Principles \& Practice of Oncology. 8th edition, Lippincott Williams \& Wilkins 2008.

2. Weinberg RA. The Biology of Cancer. Garland Science 2007.

3. Fidler IJ. The pathogenesis of cancer metastasis: the 'seed and soil' hypothesis revisited. Nat Rev Cancer 2003; 3:453-8

4. Hsu M-Y, Meier F, Herlyn M. Melanoma development and progression: a conspiracy between tumor and host. Differentiation (2002) 70:522-36.

5. DeNardo D, Johansson M, Coussens L. Immune cells as mediators of solid tumor metastasis. Cancer Met Rev 2008; 27:11-8.

6. Huang B, Zhao J, Unkeless JC, Feng ZH, Xiong H. TLR signaling by tumor and immune cells: a double-edged sword. Oncogene 2008; 27: 218-24.

7. Ramirez-Montagut T, Turk MJ, Wolchok JD, GuevaraPatino JA, Houghton AN. Immunity to melanoma: unraveling the relation of tumor immunity and autoimmunity. Oncogene 2003; 22:3180-7.

8. Baitsch L, Baumgaertner P, Devêvre E, Raghav S.K, Legat A, Barba L. et al. Exhaustion of tumor-specific CD8+ T cells in metastases from melanoma patients. J Clin Invest 2011; 121(6):2350-60.

9. Ahmadzadeh M, Johnson LA, Heemskerk B, Wunderlich JR, Dudley ME, White DE. et al. Tumor antigenspecific CD8 T cells infiltrating the tumor express high levels of PD-1 and are functionally impaired. Blood 2009; 114(8):1537-44.

10. Correll A, Tuettenberg A, Becker C, Jonuleit H. Correll A, Tuettenberg A. et al. Increased regulatory $\mathrm{T}$-cell frequencies in patients with advanced melanoma correlate with a generally impaired $\mathrm{T}$-cell responsiveness and are restored after dendritic cell-based vaccination. Exp Dermatol 2010; 19: e213-21.

11. Ahmadzadeh M, Felipe-Silva A, Heemskerk B, Powell DJ Jr, Wunderlich JR, Merino MJ et al. FOXP3 expression accurately defi nes the population of intratumoral regulatory $\mathrm{T}$ cells that selectively accumulate in metastatic melanoma lesions. Blood 2008;112: 4953-60.
12. Park SH, Kyin T, Bendelac A, Carnaud C. The contribution of NKT cells, NK cells, and other gamma-chaindependent non-T non-B cells to IL-12-mediated rejection of tumors. J Immunol 2003; 170:1197-201.

13. Whiteside TL, Herberman RB. The role of natural killer cells in immune surveillance of cancer. Curr Opin Immunol 1995; 7(5):704-10.

14. Burke S, Lakshmikanth T, Colucci F, Carbone E. New views on natural killer cell-based immunotherapy for melanoma treatment. Trends in Immunology 2010; 31:339-45.

15. Smyth MJ, Teng MW, Swann J, Kyparissoudis K, Godfrey DI, Hayakawa Y. CD4+CD25+ regulatory T cells suppress NK cell-mediated immunotherapy of cancer. J Immunol 2006; 176(3):1582-7.

16. Crawford A, Macleod M, Schumacher T, Corlett L, Gray D. Primary T cell expansion and differentiation in vivo requires antigen presentation by B cells. J Immunol 2006; 176: 3498-506.

17. Bouaziz J D, Yanaba K, Venturi G.M, Wang Y, Tisch R.M, Poe J.C et al. Therapeutic B cell depletion impairs adaptive and autoreactive CD4+ $\mathrm{T}$ cell activation in mice. Proc Natl Acad Sci USA 2007; 104: 20878-83.

18. Coughlin C.M, Vance B.A, Grupp S.A, Vonderheide R.H. RNAtransfected CD40-activated B cells induce functional T-cell responses against viral and tumor antigen targets: implications for pediatric immunotherapy. Blood 2004; 103: 2046-54.

19. DiLillo D.J, Matsushita T, Tedder T.F. B10 cells and regulatory $\mathrm{B}$ cells balance immune responses during inflammation, autoimmunity, and cancer. Ann NY Acad Sci 2010; 1183: 38-57.

20. Yanaba K, Bouaziz J-D, Haas K.M, Poe J.C, Fujimoto $M$, Tedder T.F. A regulatory B cell subset with a unique CD1dhiCD5+ phenotype controls T cell-dependent inflammatory responses. Immunity 2008; 28: 639-50.

21. Matsushita T, Yanaba K, Bouaziz J-D, Fujimoto M, Tedder T.F. Regulatory B cells inhibit EAE initiation in mice while other B cells promote disease progression. J Clin Invest 2008; 118: 3420-30.

22. Houghton A.N, Uchi H, Wolchok J.D. The role of the immune system in early epithelial carcinogenesis: B-ware the double-edged sword. Cancer Cell 2005; 7:403-5.

23. de Visser K.E, Korets L.V, Coussens L.M. De novo carcinogenesis promoted by chronic inflammation is $\mathrm{B}$ lymphocyte dependent. Cancer Cell 2005; 7:411-23.

24. Radosavljevic G, Jovanovic I, Majstorovic I, Mitrovic M, Lisnic VJ, Arsenijevic N. et al. Deletion of galectin-3 in the host attenuates metastasis of murine melanoma by modulating tumor adhesion and NK cell activity. Clin Exp Metastasis 2011; 28(5):451-62.

25. Jovanović I, Radosavljević G, Pavlović S, Zdravković N, Martinova K, Knežević M. et al. Th-17 cells as novel participant in immunity to breast cancer. Serb J Exp Clin Res 2010; 11(1):7-17.

26. Edward M, Gold JA, McKie MR. Modulation of melanoma cell adhesion to basement membrane components by retinoic acid. J Cell Sci 1989; 93:155-61. 
27. Jovanovic I, Radosavljevic G, Mitrovic M, Lisnic Juranic V, McKenzie ANJ, Arsenijevic N. et al. ST2 Deletion Enhances Innate and Acquired Immunity to Murine Mammary Carcinoma. Eur J Immunol 2011; 41:1902-12.

28. Janjic BM, Lu G, Pimenov A, Whiteside TL, Storkus WJ, Vujanovic NL. Innate direct anticancer effector function of human immature dendritic cells. I. Involvement of an apoptosis-inducing pathway. J Immunol 2002; 168(4):1823-30.

29. Richards J, McNally B, Fang X, Caligiuri M.A, Zheng P, Liu Y. Tumor growth decreases NK and B cells as well as common lymphoid progenitor. PloS ONE 2008; 3(9):e3180.

30. Overwijk WW, Restifo NP. B16 as a mouse model for human melanoma. Curr Protoc Immunol 2001; Chapter 20:Unit 20.1.

31. Imai S, Nio Y, Shiraishi T, Tsubono M, Morimoto H, Tseng CC. et al. Effects of splenectomy on pulmonary metastasis and growth of SC42 carcinoma transplanted into mouse liver. J Surg Oncol 1991; 47(3): 178-87.

32. Sonoda K, Izumi K, Matsui Y, Inomata M, Shiraishi N, Kitano S. Decreased growth rate of lung metastatic lesions after splenectomy in mice. Eur Surg Res 2006; 38(5): 469-75.

33. DiLillo D. J, Yanaba K, Tedder T.F. B Cells Are Required for Optimal CD4+ and CD8+ T Cell Tumor Immunity: Therapeutic B Cell Depletion Enhances B16 Melanoma Growth in Mice. J Immunology 2010; 184: 4006-16.

34. Witz IP. The tumor microenvironment: the making of a paradigm. Cancer Microenviron 2009; 2(Suppl 1):9-17.

35. Hu M, Polyak K. Microenvironmental regulation of cancer development. Curr Opin Genet Dev 2008; 18:27-34.

36. Mbeunkui F, Johann DJ Jr. Cancer and the tumor microenvironment: a review of an essential relationship. Cancer Chemother Pharmacol 2009; 63:571-82.
37. Alshaker H.A, Matalka K.Z. IFN-g, IL-17 and TGF-b involvement in shaping the tumor microenvironment: The significance of modulating such cytokines in treating malignant solid tumors. Cancer Cell International 2011; 11:33 doi:10.1186/1475-2867-11-33.

38. Zou W. Regulatory T cells, tumour immunity and immunotherapy. Nat Rev Immunol 2006; 6(4):295-307.

39. Steitz J, Bruck J, Lenz J, Knop J, Tuting T. Depletion of CD25+ CD4+ T-cells and treatment with tyrosinaserelated protein 2-transduced dendritic cells enhance the interferon $\alpha$-induced, CD8+ T-cell-dependent immune defense of B16 melanoma. Cancer Res 2001; 61: 8643-6.

40. Jones E, Dahm-Vicker M, Simon A. K, Green A, Powrie F, Cerundolo V. et al. Depletion of CD25+ regulatory cells results in suppression of melanoma growth and induction of autoreactivity in mice. Cancer Immun 2002; 2: 1.

41. Ruggeri L, Capanni M, Urbani E, Perruccio K, Shlomchik W.D, Tosti A. et al. Effectiveness of donor natural killer cell alloreactivity in mismatched hematopoietic transplants. Science 2002; 295: 2097-00.

42. O'Hanlon LH. Natural born killers: NK cells drafted into the cancer fight. J Natl Cancer Inst 2004; 96: 651-3.

43. Borg C, Terme M, Taieb J, Menard C, Flament C, Robert C. et al. Novel mode of action of c-kit tyrosine kinase inhibitors leading to NK cell-dependent antitumor effects. J Clin Invest 2004; 114: 379-88.

44. Ghiringhelli F, Ménard C, Terme M, Flament C, Taieb J, Chaput N. et al. CD4+CD25+ regulatory T cells inhibit natural killer cell function in a transforming growth factor- $\beta$-dependent manner. J Exp Med 2005; 202(8):1075-85.

45. Ralainirina N, Poli A, Michel T, Poos L, Andrès E, Hentges F. et al. Control of NK cell functions by CD4+CD25+ regulatory T cells. Journal of Leukocyte Biology 2007; 81:144-53. 